Article

\title{
Catholic and Charismatic: A Study in Personality Theory within Catholic Congregations
}

\section{Leslie J Francis $^{1}{ }^{1}$, Stephen H. Louden ${ }^{2, \dagger}$ and Mandy Robbins ${ }^{3}$}

1 Warwick Religions \& Education Research Unit, Institute of Education, The University of Warwick, Coventry, CV4 7AL, UK

2 St Mary's Centre, Llys Onnen, Abergwygregyn, LL33 0LD, UK

3 Division of Psychology, Glyndŵr University, Plas Coch Campus, Wrexham, LL11 2AW, UK

$\dagger$ Deceased, 17 January 2013. His co-authors dedicate this paper to his memory.

* Author to whom correspondence should be addressed; E-Mail: leslie.francis@warwick.ac.uk; Tel.: +44-(0)24-7652-2539; Fax: +44-(0)24-7657-2638.

Received: 16 February 2013; in revised form: 19 April 2013 / Accepted: 22 April 2013 / Published: 26 April 2013

\begin{abstract}
This study set out to conceptualise and measure Charismatic orientation (openness to charismatic experience) and traditional Catholic orientation (Catholic identity) among a sample of 670 Catholic churchgoers in order to test whether attachment to Catholic Charismatic Renewal strengthened or weakened the sense of traditional Catholic identity among churchgoing Catholics. This research question was set within the broader consideration of the location of Charismatic orientation and Catholic orientation within Eysenck's three dimensional model of personality. The data revealed a strong positive association between Charismatic experience and Catholic identity. Higher scores on the index of Charismatic orientation were associated with higher extraversion scores, with higher neuroticism scores, and with higher levels of mass attendance and personal prayer. Higher scores on the index of Catholic orientation were associated with being female, being older, higher neuroticism scores, and higher levels of mass attendance and personal prayer.
\end{abstract}

Keywords: personality; religion; Catholic; congregation studies; Catholic charismatic renewal 


\section{Introduction}

During the early twentieth century Charismatic expression in Christian belief and practice became established in England and Wales through what are known as the classical Pentecostal Churches, including the Assemblies of God and Elim [1]. The Charismatic phenomenon has spread more recently in England and Wales through the neo-Pentecostal networks of churches, often in connection with Black-led or Black-majority churches [2]. During the 1960s the Charismatic Movement found expression through the main-line denominations in England and Wales, including the Anglican Church [3] and the Roman Catholic Church.

The emergence of the Charismatic Movement within the Roman Catholic Church is traced to a weekend retreat arranged in February 1967 by faculty members for students from Duquesne University, near Pittsburg, Pennsylvania, USA. At this retreat, many present had a transforming experience that included speaking in tongues, the classic hallmark of the classical Pentecostal Churches and of the Charismatic Movement already emerging within Protestant Churches. The developments of this movement within the Roman Catholic Church over the next few years, 1967-1971, have been chronicled by Connelly [4], and discussed by O'Connor [5]. News of the Duquesne outpouring of the Holy Spirit spread quickly, especially to the campuses of the University of Notre Dame, Indiana, and Michigan State University in East Lansing, Michigan, followed a few months later by the University of Michigan in Ann Arbor. By the early 1970s the movement became clearly re-styled Catholic Charismatic Renewal (CCR), was consolidated by the first international conference held outside the USA in Rome in 1975, and was spreading through Australia, Western Europe, the Philippines and Latin America. Summing up the situation in the early 2000s, Hocken writes as follows.

In Europe, the strength of CCR has varied from country to country, with Italy and France among the stronger. Though in general CCR has not been growing in Western Europe, it has not generally seen a sharp reduction in participation. In Eastern Europe, the collapse of Communism has enabled CCR to develop freely with growth particularly visible in Slovakia and in Lithuania. In Africa, Asia and Latin America, CCR has mostly continued to grow. Much greater numbers are involved than in Europe and North America, with extraordinary crowds gathering for example in Brazil and in India ([6], p. 207).

The emergence of the Charismatic Movement within the Roman Catholic Church raises a number of intriguing questions relevant to the fields of the empirical psychology of religion and empirical theology. For example, Heirich [7], Halama and Halamová [8] and Siekierski [9] explored the process of religious conversion within Catholic Charismatic Renewal. Halama and Halamová analysed 30 conversion experiences published by Catholic Charismatic Renewal in Bratislava, Slovakia, between 1999 and 2002. These data were analysed to address questions concerning the precedents of conversion, the process of conversion, and the consequences of conversion in personal life. The results of the analysis showed that the typical process of conversion within the context of the movement was preceded by some contact with religious issues in childhood and experiencing some problem in the period before conversion. The conversion was stimulated by meeting a religious person and by attendance at prayer meetings. Such contacts led to the experience of God's presence and a cognitive insight into religious matters. The consequences of conversion included radical changes in spiritual life, increasing subjective well-being, improving social life, and solving the problem that had preceded the conversion. 
As yet, very little empirical research has examined the impact of the Charismatic Movement among the main-line denominations in England and Wales, and this is especially the case concerning the Roman Catholic Church. The present study intends to initiate empirical enquiry among Catholic congregations regarding the impact of Catholic Charismatic Renewal and to do so by posing a broad research question. The research question concerns whether Catholic Charismatic Renewal is strengthening or weakening traditional Catholic identity within the Roman Catholic Church in England and Wales. In other words, are those individuals within Catholic congregations who are themselves influenced by Catholic Charismatic Renewal, more or less likely to value traditional Catholic identity? In order to operationalise this research question, engagement is sought with three developing fields of research, concerning: the conceptualisation and assessment of Charismatic orientation; the conceptualisation and assessment of traditional Catholic orientation; and the role of personality theory in shaping individual differences in Charismatic orientation and traditional Catholic orientation.

\subsection{Assessing Charismatic Orientation}

Empirical research concerned with assessing the correlates of Charismatic experience, predisposition or orientation have operationalised these notions in a variety of ways. Jones, Francis, and Craig [10] distinguished between Charismatics and non-Charismatics by the item 'Would you describe yourself as being influenced by the Charismatic Movement?' assessed on a three-point scale: yes, don't know, no. Francis and Robbins [11] assessed Charismatic orientation in terms of glossolalic frequency rated on a six-point scale: nearly every day, at least once a week, at least once a month, occasionally, used to but not now, never. Randall [12] assessed Charismatic orientation by means of a seven-point semantic differential grid. Participants were asked, 'Have you been influenced by the Charismatic Movement?', and the poles of the grid were anchored by the two terms: positively and negatively.

A series of five studies reported by Francis and Jones [13], Francis and Thomas [14], Robbins, Hair, and Francis [15], Louden and Francis [16], and Francis and Littler [17] began the process of developing a better nuanced scale of Charismatic orientation. In the first study, Francis and Jones developed a five-item scale comprising the following five items: Would you describe yourself as a 'born again Christian?'; Do you belong to a church or group which has 'born again Christians?'; Have you ever had a religious experience which you would describe as 'being born again'?; Have you ever had an occasion when you felt moved to pray or speak in a language unknown to you?; Would you agree with the statement 'born again Christians are the most effective witness to the Gospel?'. It can be properly objected that the items are neither straightforward nor properly representative of the Charismatic experience.

Influenced by collaboration with Newton Malony [18], Francis and Thomas proposed a 14-item scale, including items like, 'speaking or praying in tongues', 'receiving the Baptism of the Holy Spirit'. Respondents were asked to assess the importance of these experiences to their faith on a five-point scale, ranging from a 'great deal' to 'none at all'. The 14-item scale achieved an alpha coefficient of 90 [19] among a sample of 222 clergymen in the Church in Wales. Robbins, Hair, and Francis extended this scale by adding one further item: 'Experiencing the healing work of the Holy Spirit'. This 15-item scale achieved an alpha coefficient of .92 among a sample of 172 clergymen 
serving in the Church of England. Then this 15-item scale was employed by Louden and Francis in a study among 1,468 Roman Catholic priests, where it achieved an alpha coefficient of .91.

Subsequently, Francis and Littler revisited the 15-item scale employed by Robbins, Hair, and Francis, and by Louden and Francis in light of three concerns. They argued that some of the items lacked clarity. They argued that 15 items presented a restricted range of Charismatic phenomena. They argued that there were benefits in developing the 21-item index of Charismatic orientation to mirror the 21-item index of mystical orientation proposed by Francis and Louden [20]. Francis and Littler, drawing on data provided by a sample of 232 clergymen serving in the Church in Wales, reported an alpha coefficient of .96 for this new 21-item measure which they named The Francis-Littler Charismatic Orientation Scale (COS).

\subsection{Assessing Traditional Catholic Orientation}

A different strand of research, running parallel with the studies concerned with assessing mystical orientation and Charismatic orientation, set out to operationalise the notion of Anglo-Catholic orientation. The notion of Anglo-Catholic orientation is set within the context of the historical roots and development of the Church of England and the Anglican Communion. The Anglican Church claims the distinction of being both Reformed and Catholic, occupying a highly distinctive position among the various churches emerging from the Reformation. During the nineteenth century both the Reformed roots and the Catholic roots of the Church of England were, as it were, rediscovered and re-emphasized through the emergence of the Tractarian or Anglo-Catholic Movement [21] and through the emergence of the Evangelical Movement, reflecting the Reformed tradition [22]. Both movements tried to capture the soul of the Church of England by investing in seminaries in order to train clergy in their distinctive traditions and by collecting advowsons in order to influence the appointment of clergy to parishes through the patronage system.

To capture the distinctive emphases of the Anglo-Catholic wing of the Anglican Church, Francis and Thomas [23] developed a nine-item scale of Anglo-Catholic orientation that generated satisfactory internal consistency alpha reliability coefficient of .91. Building on this work in a subsequent study, Francis and Littler [24] developed the 21-item Francis-Littler Anglo-Catholic Orientation Scale. This instrument contained the following items: genuflecting before the Blessed Sacrament; using incense in worship; making pilgrimages to holy shrines; devotion to the Blessed Virgin Mary; use of vestments by the priest; calling the priest 'Father'; making the Stations of the Cross; seeing statues in church; receiving absolution from a priest; venerating the Saints; praying for the dead; signing myself with the sign of the cross; saying the Rosary; receiving the imposition of ashes; fasting before receiving the Blessed Sacrament; attending Mass; using holy water; witnessing ceremonial ritual in worship; saying the Angelus; receiving the Blessed Sacrament without touching it; and lighting votive candles. As yet no comparable measure has been developed for use in the Roman Catholic Church.

\subsection{Assessing Personality}

The connection between religious experience and personality has been of significant interest within the psychology of religion over a number of years. The precise ways in which the research questions can be posed vary from one scientific model of personality to another. Within this field, various studies 
have drawn on the 16 factor model of personality proposed by Cattell [25], the three dimensional model proposed by Eysenck [26], the five factor model proposed by Costa and McCrae [27] and the four component model proposed by The Myers-Briggs Type Indicator [28]. In their study of the personality characteristics of Pentecostal ministry candidates, Francis and Kay [29] argued that the Eysenckian dimensional model of personality was particularly pertinent in light of the way in which, although concerned with calibrating individual differences within normal personality, the Eysenckian model affirms the continuity between normal personality and psychopathology, as reflected in the nomenclature of two of the dimensions of normal personality in terms of neuroticism and psychoticism. This model is, therefore, capable of testing the extent to which religious experience may be correlated with precursors of psychological pathology. Francis and Kay proceeded to review earlier theories concerning the connection between Charismatic phenomena and psychopathology and to contextualise this literature within the Eysenckian framework.

The Eysenckian dimensional model of personality argues that individual differences can be most adequately and economically summarised in terms of three orthogonal higher order factors: extraversion, neuroticism, and psychoticism. The Eysenckian personality measures also routinely include a lie scale.

The first dimension of the Eysenckian model is defined by the extraversion scale. This continuum moves from introversion, through ambiversion, to extraversion. In the test manual, Eysenck and Eysenck characterise high scorers on the extraversion scale as sociable individuals who like parties, have many friends, need to have people to talk to and prefer meeting people to reading or studying alone. Typical extraverts crave excitement, take chances, act on the spur of the moment, are carefree, easygoing and optimistic. Low scorers on the extraversion scale are characterised by the opposite set of traits.

The second dimension of the Eysenckian model is defined by the neuroticism scale. This continuum moves from emotional stability, through emotional lability, to neurotic disorder. In the test manual, Eysenck and Eysenck characterise high scorers on the neuroticism scale as anxious, worrying individuals who are moody and frequently depressed, likely to sleep badly and to suffer from psychosomatic disorders. Low scorers on the neuroticism scale are characterised by an absence of these traits.

The third dimension of the Eysenckian model is defined by the psychoticism scale. This continuum moves from tendermindedness, through toughmindedness, to psychotic disorder. In their foundation text on psychoticism, Eysenck and Eysenck [30] characterise high scorers on the psychoticism scale as not caring for people, lacking in feeling and empathy and altogether insensitive. Low scorers on the psychoticism scale are characterised as empathetic, unselfish, altruistic, warm, peaceful and generally pleasant, although possibly socially indecisive individuals.

While the lie scales were originally included within the Eysenckian measures to detect the tendency to 'fake good', subsequent studies have interpreted lie scale scores as measuring social acquiescence or conformity [31], lack of self-insight [32], immaturity [33], and paradoxically greater honesty and truthfulness [34].

\subsection{Personality and Religious Orientation}

Six previous studies have explored the connection between Charismatic orientation and the Eysenckian dimensional model of personality: Francis and Thomas [35] among 222 Anglican 
clergymen serving in the Church in Wales; Francis and Jones [36] among 368 committed Christian adults attending courses concerned with personality and spirituality; Robbins, Hair, and Francis [37] among 172 Anglican clergymen serving in the Church of England; Louden and Francis [38] among 1,468 Roman Catholic priests serving in England and Wales; Francis and Robbins [39] among 991 male clergy, from a range of denominations, affiliated with the Evangelical Alliance in the United Kingdom; and Francis and Littler [40] among 232 clergymen serving in the Church in Wales.

Drawing together the insights of previous research on Charismatic phenomena, especially related to glossolalia, Francis and Kay [41] argued that, within the context of the Eysenckian dimensional model of personality, glossolalia may be associated with a distinctive personality profile. First, they suggested that there was a considerable body of research and theory to promote the hypothesis that glossolalics should score higher on the neuroticism scale, including early theories advanced by Mackie [42] and Cutten [43], and subsequent work by Vivier [44], Lapsley and Simpson [45], Pattison [46] and Kildahl [47]. On the other hand, a contradictory strand of research suggested that glossolalia may function as a tension-reducing device which may promote psychological health [48]. Second, they suggested that there was evidence to promote the hypothesis that glossolalics should score lower on the psychoticism scale, on the grounds that individuals who score low on psychoticism condition more readily [49] and that glossolalia is learned behaviour [50]. Third, they suggested that there was evidence to promote the hypothesis that glossolalics should score higher on the lie scale, on the grounds that the lie scale actually measures lack of self-insight and immaturity [51] and that glossolalia represents regressive behaviour [52]. They did not, however, propose a theoretical basis for linking glossolalia with extraversion. Taken together these hypotheses suggested that glossolalics may be characterised by elevated neuroticism scores, higher lie scale scores and lower psychoticism scores.

Although Francis and Kay's review of the literature found no grounds on which to link Charismatic phenomena and extraversion, one secure conclusion to emerge from all six studies was that of a significant positive correlation between Charismatic orientation and extraversion scores. In other words, extraverts were more likely than introverts to be associated with the Charismatic Movement.

A second consistent conclusion to emerge from all six studies was that of no significant correlation (either positive or negative) between Charismatic orientation and psychoticism scores. In other words, there was no support for Francis and Kay's hypothesis that Charismatic phenomena (and glossolalia in particular) will be associated with lower psychoticism scores.

A third consistent conclusion to emerge from all six studies was that of no significant positive correlation between Charismatic orientation and lie scale scores. In other words, there was no support for Francis and Kay's hypothesis that Charismatic phenomena (and glossolalia in particular) will be associated with higher lie scale scores.

The relationship between Charismatic orientation and neuroticism scores was not consistent within the six studies: the three studies by Robbins, Hair, and Francis, by Louden and Francis and by Francis and Littler reported no significant correlation (either positive or negative) between the two variables; the three studies by Francis and Thomas, Francis and Jones, and Francis and Robbins reported significant negative correlations between Charismatic orientation and neuroticism scores. In other words, there was no support for Francis and Kay's hypothesis that Charismatic phenomena will be associated with higher neuroticism scores. Rather there is some evidence to suggest that Charismatic orientation is associated with emotional stability, not with emotional instability. 
Two previous studies have explored the connection between Anglo-Catholic orientation and the Eysenckian dimensional model of personality: Francis and Thomas among 222 clergymen serving in the Church in Wales; and Francis and Littler among 232 clergymen serving in the Church in Wales. Both studies found no significant correlations between Anglo-Catholic orientation and the extraversion scale, the psychoticism scale and the lie scale. One of the two studies found a significant positive correlation between Anglo-Catholic orientation and the neuroticism scale, but the other study did not. What is clear from comparing the two sets of studies (one set concerning charismatic orientation and the other set concerning Anglo-Catholic orientation) is that charismatic orientation and Anglo-Catholic orientation occupy different positions within Eysenckian psychological space.

\section{Research Questions}

Against this background, the present study was designed to address five main research questions. First, building on the work of Francis and Littler who tested their 21-item scale of Charismatic orientation among Anglican clergy, the present study aims to develop and to test a 21-item scale of Charismatic orientation among Catholic churchgoers. Second, building on the work of Francis and Littler who tested their 21-item scale of Anglo-Catholic orientation among Anglican clergy, the present study aims to develop and to test a 21 -item scale of traditional Catholic orientation among Catholic churchgoers. Third, the present study aims to employ these two instruments to profile the levels of traditional Catholic orientation and Charismatic orientation among Catholic churchgoers and to test whether these two orientations are complementary or contradictory: within the Catholic community does Charismatic orientation contribute positively to enhancing traditional Catholic identity or detract from traditional Catholic identity? Fourth, by including measures of personal prayer and mass attendance, the present study aims to examine the association between Charismatic orientation and traditional Catholic orientation on the one hand, and personal religious practices on the other hand. Fifth, by including the Eysenckian personality measure, the present study aims to extend the earlier research, most recently reported by Francis and Littler, on locating Charismatic orientation within Eysenck's three dimensional model of personality, and to set alongside this data on the location of traditional Catholic orientation within this model.

\section{Method}

\subsection{Procedure}

Participants attending the main Sunday celebrations of mass in three Catholic churches were invited to complete a questionnaire printed on two sides of A4 paper. The presiding priest (the second author serving locum duty in these churches) introduced the project and received a high level of interest in the research. Successfully completed questionnaires were returned by 670 participants. The three churches were not noted for particular influence from or involvement with Catholic Charismatic Renewal.

\subsection{Measures}

Traditional Charismatic orientation was assessed by the specially developed 21-item Francis-Louden Traditional Charismatic Orientation Scale (TCharOS). Respondents were asked to assess 'how 
important each experience is to your own faith', using a five-point scale anchored by: $1=1$ low importance, $3=$ medium importance, $5=$ high importance. Catholic orientation was assessed by the specially developed Francis-Louden Catholic Orientation Scale (CathOS). Respondents were asked to assess 'how important each experience is to your own faith', using a five-point scale anchored by: $1=$ low importance, 3 = medium importance, $5=$ high importance.

Personality was assessed by the abbreviated form of the Revised Eysenck Personality Questionnaire (EPQR-A). This instrument proposed four six-item measures (extraversion, neuroticism, psychoticism, and lie scale), using a two-point scale: $0=$ no, $1=$ yes [53].

Mass attendance was assessed on a six-point scale: daily, weekly, monthly, six times a year, once a year, and never.

Personal prayer was assessed as a four-point scale: daily, at least weekly, sometimes, and never.

\subsection{Sample}

The sample of 670 participants comprised: 193 men, 466 women and 11 individuals of undisclosed sex; 55 individuals under the age of twenty, 14 in their twenties, 63 in their thirties, 79 in their forties, 123 in their fifties, 197 in their sixties, 132 aged seventy or over, and 7 of undisclosed age. The majority of participants (658) described themselves as Catholics, with a few representative from other Christian denominations, and just 2 describing themselves as unaffiliated to any Christian denomination.

\section{Results}

Step one of the data analysis examined the public religiosity (in terms of mass attendance) and the personal religiosity (in terms of personal prayer) of the participants. Overall there was a high level of religious practices. In terms of public religiosity, $9 \%$ attended mass daily and a further $86 \%$ attended mass weekly; just 5\% attended mass less often than weekly, with $4 \%$ attending monthly and $1 \%$ less than monthly. In terms of personal religiosity, 64\% engaged in personal prayer daily and a further $19 \%$ engaged in personal prayer at least weekly, with $12 \%$ checking the 'sometimes' category and $1 \%$ checking the 'never' category.

Step two of the data analysis explored the theme of Charismatic orientation. Table 1 presents the 21 items of the Francis-Louden Charismatic Orientation Scale (CharOS) in the order in which they were presented in the survey, together with the item rest-of-test correlations and the proportions of the participants who rated the importance of the experience for their own faith at the level of four or five on the five-point scale. The scale achieved the satisfactory alpha coefficient of .89 .

The percentage endorsement of the items reveals the way in which the issues included in the measure successfully differentiate different levels of charismatic orientation, from those issues that attract wide-spread endorsement (and suggest a broad-based predisposition or openness to charismatic experience) to those issues that attract low endorsement. In terms of a broad-based predisposition or openness to charismatic experience, five of the items were endorsed by at least two-thirds of the participants: $89 \%$ rated receiving baptism of the Holy Spirit; $79 \%$ rated praying for others to be saved; $78 \%$ rated feeling God's Spirit within me; 70\% rated experiencing the work of the Holy Spirit; and $66 \%$ rated hearing God speak to me. A further three of the items were endorsed by at least half of the 
participants: $62 \%$ rated feeling led by God to perform a specific action, $55 \%$ rated praying in the Spirit; and 50\% rated sharing in open and informal worship.

Table 1. Charismatic Orientation Scale: item rest of scale correlations and item endorsement.

\begin{tabular}{llc}
\hline & $\mathbf{r}$ & $\mathbf{\%}^{\mathbf{1}}$ \\
\hline having a conversion experience & .41 & 29 \\
speaking or praying in tongues & .45 & 29 \\
experiencing the healing work of the Holy Spirit & .47 & 70 \\
attending charismatic prayer-group meetings & .52 & 19 \\
receiving the baptism of the Holy Spirit & .27 & 89 \\
receiving 'a picture' from the Lord & .55 & 43 \\
hearing God speak to me & .52 & 66 \\
feeling God's Spirit within me & .43 & 78 \\
being born again & .58 & 30 \\
prophesying & .55 & 17 \\
interpreting tongues & .59 & 16 \\
laying hands on someone for healing & .58 & 38 \\
sharing in open and informal worship & .39 & 50 \\
praying for others to be saved & .41 & 79 \\
receiving 'a word of knowledge' & .59 & 41 \\
being 'slain in the Spirit' & .57 & 18 \\
singing in the Spirit & .53 & 43 \\
seeing healings happen & .57 & 33 \\
praying in the Spirit & .55 & 55 \\
singing in tongues & .56 & 19 \\
feeling led by God to perform a specific action & .49 & 62 \\
\hline Note: ${ }^{1} \%$ is population who rated the importance of the experience for their own faith at the level of four or \\
five on the five-point scale. & &
\end{tabular}

Five of the items were endorsed by between one third and one half of the participants: $43 \%$ rated receiving 'a picture' from the Lord; 43\% rated singing in the Spirit; $41 \%$ rated receiving 'a word of knowledge'; 38\% rated laying hands on someone for healing; and 33\% rated seeing healings happen. The next set of three items were endorsed by just under one third of the participants: $30 \%$ rated being born again; 29\% rated having a conversion experience; and 29\% rated speaking or praying in tongues. The final set of five items were endorsed by just under one fifth of the participants: $19 \%$ rated attending charismatic prayer-group meetings; $19 \%$ rated singing in tongues; $18 \%$ rated being 'slain in the Spirit'; 17\% rated prophesying; and 16\% rated interpreting tongues.

Step three of the data analysis explored the theme of traditional Catholic orientation. Table 2 presents the 21 items of the Francis-Louden Traditional Catholic Orientation Scale (TCathOS) in the order in which they were presented in the survey, together with the item rest-of-test correlations and the proportions of the participants who rated the importance of the experience for their own faith at the level of four or five on the five-point scale. The scale achieved the satisfactory alpha coefficient of .89 .

The percentage endorsement of the items reveals the way in which the issues included in the measure successfully differentiate different levels of traditional Catholic orientation, from those issues that attract wide-spread endorsement (and suggest a broad-based predisposition or openness to 
traditional Catholic experience) to those issues that attract lower endorsement. In terms of a broad-based predisposition or openness to traditional Catholic experience, eight of the items were endorsed by at least two-thirds of the participants: $91 \%$ rated going to the vigil or Sunday mass; $87 \%$ rated making the sign of the cross; $86 \%$ rated genuflecting before the Blessed Sacrament; $82 \%$ rated devotion to the Blessed Virgin Mary; 77\% rated praying for souls in purgatory; 76\% rated being loyal to the Pope; $73 \%$ rated attending a Requiem Mass; and 72\% rated visiting the Blessed Sacrament. A further four items were endorsed by at least half of the participants: $65 \%$ rated the use of vestments by the priest; $63 \%$ rated saying the Rosary; 59\% rated making the Stations of the Cross; and 54\% rated lighting a votive candle.

Table 2. Traditional Catholic Orientation Scale: item rest of scale correlations and item endorsement.

\begin{tabular}{lll}
\hline & $\mathbf{r}$ & $\mathbf{\%}^{\mathbf{1}}$ \\
\hline genuflecting before the Blessed Sacrament & .48 & 86 \\
using incense in worship & .44 & 35 \\
going to the vigil or Sunday Mass & .22 & 91 \\
devotion to the Blessed Virgin Mary & .54 & 82 \\
use of vestments by the priest & .49 & 65 \\
making the Stations of the Cross & .57 & 59 \\
attending Devotions and Benediction & .58 & 47 \\
going to Confession & .43 & 45 \\
venerating Saints & .55 & 42 \\
praying for the souls in purgatory & .54 & 77 \\
making a Novena & .66 & 48 \\
visiting the Blessed Sacrament & .54 & 72 \\
saying the Rosary & .65 & 63 \\
making the Sign of the Cross & .43 & 87 \\
attending a Requiem Mass & .37 & 73 \\
being loyal to the Pope & .52 & 76 \\
buying a Catholic newspaper & .43 & 21 \\
going on pilgrimage to a Catholic shrine & .53 & 45 \\
saying the Angelus & .60 & 31 \\
venerating your Guardian Angel & .53 & 45 \\
lighting votive candles & .47 & 54 \\
\hline
\end{tabular}

Note: ${ }^{1} \%$ is population who rated the importance of the experience for their own faith at the level of four or five on the five-point scale.

Six of the items were endorsed by between two-fifths and one half of the participants: $48 \%$ rated making a Novena; 47\% rated attending Devotions and Benediction; 45\% rated going to confession; $45 \%$ rated going on pilgrimage to a Catholic shrine; $45 \%$ rated venerating your Guardian Angel; and $42 \%$ rated venerating Saints. The final set of three items were endorsed by under two-fifths of the participants: $35 \%$ rated using incense in worship; $31 \%$ rated saying the Angelus; and $21 \%$ rated buying a Catholic newspaper.

Step four of the data analysis explored the correlations between the index of Charismatic orientation, the index of traditional Catholic orientation, the four Eysenckian measures (extraversion, neuroticism, psychoticism, and lie scale), two measures of religious practice (mass attendance and 
personal prayer), and two personal factors (sex and age). Table 3, employing the Pearson correlation coefficient, demonstrates the importance of both sex and age. Women recorded higher scores on the index of traditional Catholic orientation, on the measure of personal prayer, on the neuroticism scale, and on the lie scale. Older participants recorded higher scores on the index of traditional Catholic orientation, mass attendance, personal prayer, neuroticism, and the lie scale; older participants recorded lower scores on extraversion and psychoticism.

Table 3. Correlation matrix.

\begin{tabular}{|c|c|c|c|c|c|c|c|c|c|}
\hline & Sex & Age & Ext & Neu & Psy & Lie & Pra & Mas & Cat \\
\hline Charismatic & .00 & .02 & $.10^{* *}$ & $.13^{* * *}$ & -.02 & -.00 & $.17^{* * *}$ & $.12^{* *}$ & $.60^{* * *}$ \\
\hline Catholic (Cat) & $.10^{* *}$ & $.34^{* * *}$ & -.04 & $.17^{* * *}$ & $-.10^{* *}$ & $.16^{* * *}$ & $.35^{* * *}$ & $.28^{* * *}$ & \\
\hline Mass (Mas) & -.01 & $.19^{* * *}$ & .01 & .03 & -.05 & .03 & $.23^{* * *}$ & & \\
\hline Prayer (Pra) & $.12^{* *}$ & $.30^{* * *}$ & .04 & .05 & $-.09^{*}$ & .07 & & & \\
\hline Lie Scale (Lie) & $.20^{* * *}$ & $.28^{* * *}$ & $.10^{*}$ & -.02 & -.06 & & & & \\
\hline $\begin{array}{l}\text { Psychoticism } \\
\text { (Psy) }\end{array}$ & .00 & $-.18^{* * *}$ & $.17^{* * *}$ & -.06 & & & & & \\
\hline $\begin{array}{l}\text { Neuroticism } \\
(\mathrm{Neu})\end{array}$ & $.18^{* * *}$ & $.11^{* *}$ & -.02 & & & & & & \\
\hline $\begin{array}{l}\text { Extraversion } \\
\text { (Ext) }\end{array}$ & .00 & $-.24^{* * *}$ & & & & & & & \\
\hline Age & -.01 & & & & & & & & \\
\hline
\end{tabular}

In view of the multiple correlations with age and sex, Table 4 recalculates the correlations between Charismatic orientation, traditional Catholic orientation, mass attendance, personal prayer, and personality by means of partial correlations controlling for sex and for age. Four main findings emerge from these data. First, there is a high positive correlation between Charismatic orientation and traditional Catholic orientation. Second, higher scores on the index of Charismatic orientation are associated with higher extraversion scores, with higher neuroticism scores, and with higher levels of mass attendance and personal prayer. Third, higher scores on the index of traditional Catholic orientation are associated with higher neuroticism scores, and with higher levels of mass attendance and personal prayer. Fourth, after controlling for age and sex, no significant correlations emerged between either personal prayer or mass attendance and any of the four Eysenckian measures.

Table 4. Partial correlation matrix, controlling for sex and age.

\begin{tabular}{lccccccc}
\hline & Ext & Neu & Psy & Lie & Pra & Mas & Cat \\
\hline Charismatic & $.12^{* *}$ & $.12^{* *}$ & -.04 & -.02 & $.18^{* * *}$ & $.10^{*}$ & $.62^{* * *}$ \\
Catholic (Cat) & .05 & $.12^{* *}$ & -.05 & .06 & $.27^{* * *}$ & $.20^{* *}$ & \\
Mass (Mas) & .05 & .01 & -.01 & -.03 & $.22^{* * *}$ & & \\
Prayer (Pra) & .03 & -.00 & -.05 & -.05 & & \\
Lie Scale (Lie) & -.05 & -.08 & -.02 & & & \\
Psychoticism (Psy) & $.15^{* * *}$ & -.04 & & & & \\
Neuroticism (Neu) & $-.17^{* * *}$ & & & & \\
\hline & & & & & \\
& & & &
\end{tabular}




\section{Conclusions}

This study was designed to address five main research questions. Each of these questions has now been addressed by means of analysing data provided by a sample of 670 Catholic churchgoers who agreed to complete a brief questionnaire printed on two sides of A4 paper. The questionnaire was administered by the presiding priest within the context of mass.

First, building on the work of Francis and Littler conducted among Anglican clergy, the present study set out to develop and to test a 21-item index of charismatic orientation appropriate for use among Catholic churchgoers. The resulting 21-item Francis-Louden Traditional Charismatic Orientation Scale (TCharOS) displayed good qualities of internal consistency reliability, generating an alpha coefficient of .89 , well in excess of the threshold of .65 proposed by DeVellis [54]. The instrument also possesses good face validity in terms of the range of charismatic phenomena sampled and in terms of this range discriminating between frequently endorsed and less frequently endorsed charismatic phenomena. On the basis of these data the instrument can be commended for further use.

Second, building on the work of Francis and Littler, who developed and tested their index of Anglo-Catholic orientation among Anglican clergy, the present study set out to develop and to test a 21-item index of Catholic orientation appropriate for use among Catholic churchgoers. The resulting Francis-Louden Traditional Catholic Orientation Scale (TCathOS) displayed good qualities of internal consistency, generating an alpha coefficient of .89. The instrument also possesses good face validity in terms of the range of traditional Catholic phenomena sampled and in terms of this range discriminating between frequently endorsed and less frequently endorsed traditional Catholic phenomena. On the basis of these data the instrument can be commended for further use.

Third, employing these two new measures of charismatic orientation and traditional Catholic orientation, the present study set out to profile the levels of traditional Catholic orientation and Charismatic orientation among Catholic churchgoers and to test whether these two orientations are complementary or contradictory. The data provided answers to these three questions. In terms of Charismatic orientation, there was a high level of endorsement for many of the key theological ideas promoted by the Charismatic Movement ( $89 \%$ rated highly receiving baptism in the Holy Spirit), but a lower level of endorsement for other distinctive phenomena of Charismatic experience (29\% rated highly speaking or praying in tongues). In terms of traditional Catholic orientation, there was a high level of endorsement for many of the key practices associated with the Catholic tradition (86\% rated highly genuflecting before the Blessed Sacrament), but a lower level of endorsement for many of the traditional Catholic practices (31\% rated highly saying the Angelus). In terms of the connection between Charismatic orientation and traditional Catholic orientation, the data found a large and significant positive correlation. This finding demonstrates that, within the Catholic community, Charismatic orientation may contribute positively to enhancing traditional Catholic identity rather detracting from traditional Catholic identity.

Fourth, by including measures of personal prayer and mass attendance, the present study set out to examine the association between Charismatic orientation and traditional Catholic orientation on the one hand and personal religious practices on the other hand. The data demonstrated that both higher levels of Charismatic orientation and higher levels of traditional Catholic orientation were associated with higher frequency of prayer and higher frequency of mass attendance. In other words, both 
Charismatic orientation and traditional Catholic orientation were supported by and supportive of personal and public Catholic practices. In this sense, the Charismatic Movement is associated with supporting the life of Catholic individuals.

Fifth, by including measures of the Eysenckian dimensional model of personality, the present study set out to extend the earlier research, most recently reported by Francis and Littler, on locating Charismatic orientation within Eysenck's three dimensional model of personality, and to locate traditional Catholic orientation within the same model. These data provide further confirmation of earlier research that there is a positive correlation between extraversion and Charismatic orientation. It is the extraverted members of the Catholic congregation who are most open to Charismatic experience and expression. More problematically, however, these data also demonstrate a positive correlation between Charismatic orientation and neuroticism. This finding is in contrast with the six previous studies reported by Francis and Thomas, Francis and Jones, Robbins, Hair, and Francis, Louden and Francis, Francis and Robbins, and Francis and Littler. Further studies among Catholic congregations are needed to test whether this finding is an aberration or a distinctive characteristic of the Catholic community. These data also add to knowledge by demonstrating that traditional Catholic orientation is significantly correlated with neuroticism, but independent of both psychoticism and extraversion. The link with neuroticism suggests that higher levels of traditional Catholic belief or practice may be associated with low levels of emotional stability.

A major limitation with the present study is that the research was restricted to a small number of congregations and to 670 participants. Moreover, these three congregations were all of a similar kind, in that none of them were noted for involvement with Catholic Charismatic Renewal. The research instruments and the research model have, however, proved to be useful and to offer new empirically-based insights into the impact of Catholic Charismatic Renewal on Catholic congregations in England. This research is worth replication and extension, both within England and more widely within the Catholic Church. Such replication and extension could chart and compare the association between traditional Catholic orientation and Charismatic orientation within Catholic congregations influenced strongly by Catholic Charismatic Renewal and within Catholic congregations not influenced by Catholic Charismatic Renewal.

\section{References}

1. William K. Kay. Inside Story: A History of British Assemblies of God. Mattersey: Mattersey Hall Publishing, 1990, 199.

2. William K. Kay. Apostolic Networks in Britain: New Ways of Being Church. Milton Keynes: Paternoster, 2007, 400.

3. Josephine Bax. The Good Wine: Spiritual Renewal in the Church of England. London: Church House Publishing, 1986, 224.

4. James Connelly. "The Charismatic Movement: 1967-1970." In As the Spirit Leads Us. Edited by Kevin Ranaghan and Dorothy Ranaghan. Paramus, NJ: Paulist Press, 1971, 221-32.

5. Edward D. O'Connor. The Catholic Pentecostal Movement. Notre Dame, IN: Ave Maria Press, $1971,304$. 
6. Peter Hocken. "The Impact of the Charismatic Movement on the Roman Catholic Church." Journal of Beliefs \& Values 25 (2004): 205-16. doi: 10.1080/1361767042000251618.

7. Max Heirich. "Change of heart: A Test of Some Widely Held Theories about Religious Conversion." American Journal of Sociology 83 (1977): 653-68.

8. Peter Halama, and Júlia Halamová. "Process of Religious Conversion in the Catholic Charismatic Movement: A Qualitative Analysis." Archive for the Psychology of Religion 27 (2005): 69-91. doi: dx.doi.org/10.1163/008467206774355385.

9. Konrad Siekierski. "Catholics in the Holy Spirit: The Charismatic Renewal in Poland." Religion, State and Society 40 (2012): 145-61. doi: 10.1080/09637494.2012.670009.

10. Susan H. Jones, Leslie J. Francis, and Charlotte L. Craig. "Charismatic Experience and Psychological Type: An Empirical Enquiry." Journal of European Pentecostal Theological Association 25 (2005): 39-53. doi: 10.1080/13537900802024543.

11. Leslie J. Francis, and Mandy Robbins. "Personality and Glossolalia: A Study among Male Evangelical Clergy.” Pastoral Psychology 51 (2003): 391-96.

12. Kelvin Randall. Evangelicals Etcetera: Conflict and Conviction in the Church of England's Parties. Aldershot: Ashgate, 2005, 252.

13. Leslie J. Francis, and Susan H. Jones. "Personality and Charismatic Experience among Adult Christians.” Pastoral Psychology 45 (1997): 421-28.

14. Leslie J. Francis, and T. Hugh Thomas. "Are Charismatic Ministers Less Stable? A Study among Male Anglican Clergy." Review of Religious Research 39 (1997): 61-69.

15. Mandy Robbins, James Hair, and Leslie J. Francis. "Personality and Attraction to the Charismatic Movement: A Study among Anglican Clergy.” Journal of Beliefs \& Values 20 (1999): 239-46. doi: 10.1080/1361767990200209.

16. Stephen H. Louden, and Leslie J. Francis. "Are Catholic Priests in England and Wales Attracted to the Charismatic Movement Emotionally Less Stable?" British Journal of Theological Education 11 (2001): 65-76.

17. Leslie J. Francis, and Keith Littler. "The Francis-Littler Charismatic Orientation Scale (COS): A Study in Personality Theory Among Anglican Clergymen.” PentecoStudies 10 (2011): 72-86. doi: dx.doi.org/10.1558/ptcs.v10:1.72.

18. H. Newton Malony. The Psychology of Religion for Ministry. Mahwah, NJ: Paulist Press, 1992, 184.

19. Lee J. Cronbach. "Coefficient Alpha and the Internal Structure of Tests." Psychometrika 16 (1951): 297-334.

20. Leslie J. Francis, and Stephen H. Louden. "Mystical Orientation and Psychological Type: A Study among Student and Adult Churchgoers." Transpersonal Psychology Review 4 (2000): $36-42$.

21. Kenneth Hylson-Smith. High Churchmanship in the Church of England: From the Sixteenth Century to the Late Twentieth Century. Edinburgh: T and T Clark, 1993, 440.

22. Kenneth Hylson-Smith. Evangelicals in the Church of England 1734-1984. Edinburgh: T and T Clark, 1988, 422.

23. Leslie J. Francis, and T. Hugh Thomas. "Are Anglo-Catholic Priests More Feminine? A Study Among Male Anglican Clergy." Pastoral Science 15 (1996): 15-22. 
24. Leslie J. Francis, and Keith Littler. "Churchmanship and Personality Among Clergymen in the Church in Wales: Are Anglo-Catholic Priests More Feminine?” Journal of Empirical Theology 25 (2012): 236-45. doi: dx.doi.org/10.1163/15709256-12341248.

25. Raymond B. Cattell, Herbert Eber, and Maurice Tatsuoka. Handbook for the Sixteen Personality Factor Questionnaire (16PF). Champaign, IL: Institute for Personality and Ability Testing, 1970, 197, 390.

26. Hans J. Eysenck, and Sybil B.G. Eysenck. Manual of the Eysenck Personality Questionnaire (adult and junior). London: Hodder and Stoughton, 1975, 47.

27. Paul T. Costa, and Robert R. McCrae. The NEO Personality Inventory. Odessa, FL: Psychological Assessment Resources, 1985, 101.

28. Isabelle B. Myers, and Mary H. McCaulley. Manual: A Guide to the Development and Use of the Myers-Briggs Type Indicator. Palo Alto, CA: Consulting Psychologists Press, 1985, 309.

29. Leslie J. Francis, and William K. Kay. "The Personality Characteristics of Pentecostal Ministry Candidates.” Personality Individual Differences 18 (1995): 581-94. doi: dx.doi.org/10.1016/ 0191-8869(94)00210-J.

30. Hans J. Eysenck, and Sybill B.G. Eysenck. Psychoticism as a Dimension of Personality. London: Hodder and Stoughton, 1976, 248.

31. Alf Massey. "The Eysenck Personality Inventory Lie Scale: Lack of Insight Or ...?" The Irish Journal Psychology 4 (1980), 172-74.

32. Michael J. Kirton. "Characteristics of High Lie Scorers." Psychological Reports 40 (1977): 279-280. doi: 10.2466/pr0.1977.40.1.279.

33. Leslie J. Francis, Paul R. Pearson, and William K. Kay. "Are Religious Children Bigger Liars?" Psychol. Reports 52 (1983): 551-54. doi: 10.2466/pr0.1983.52.2.551.

34. Robert Loo. "Characteristics of the Eysenck Personality Questionnaire Lie Scale and of Extreme Lie Scorers.” Psychology: A Quarterly Journal of Human Behavior 17 (1980): 5-10.

35. Leslie J. Francis, and T. Hugh Thomas. "Are Charismatic Ministers Less Stable? A Study among Male Anglican Clergy.” Review of Religious Research 39 (1997): 61-69.

36. Leslie J. Francis, and Susan H. Jones. "Personality and Charismatic Experience among Adult Christians." Pastoral Psychology 45 (1997): 421-28.

37. Mandy Robbins, James Hair, and Leslie J. Francis. "Personality and Attraction to the Charismatic Movement: A Study Among Anglican Clergy.” Journal of Beliefs \& Values 20 (1999): 239-46. doi: 10.1080/1361767990200209.

38. Stephen H. Louden, and Leslie J. Francis. "Are Catholic Priests in England and Wales Attracted to the Charismatic Movement Emotionally Less Stable?" British Journal of Theological Education 11 (2011): 65-76.

39. Leslie J. Francis, and Mandy Robbins. "Personality and Glossolalia: A Study among Male Evangelical Clergy. Pastoral Psychology 51 (2003): 391-96.

40. Leslie J. Francis, and Keith Littler. "The Francis-Littler Charismatic Orientation Scale (COS): A Study in Personality Theory Among Anglican Clergymen.” PentecoStudies 10 (2011): 72-86. doi: dx.doi.org/10.1558/ptcs.v10:1.72. 
41. Leslie J. Francis, and William K. Kay. "The Personality Characteristics of Pentecostal Ministry Candidates." Personality Individual Differences 18 (1995): 581-94. doi: dx.doi.org/10.1016/01918869(94)00210-J.

42. Alexander Mackie. The Gift of Tongues. New York, NY: G. H. Doran, 1923, 294.

43. George B. Cutten. Speaking with Tongues: Historically and Psychologically Considered. New Haven, CT: Yale University Press, 1927, 210.

44. L. Melane Vivier. "Glossolalia.” PhD diss., University of Witwatersrand, Johannesburg, South Africa, 1960.

45. James N. Lapsley, and John. H. Simpson. "Speaking in Tongues: Infantile Babble or Song of the Self." Pastoral Psychology15 (1964): 48-55.

46. E. Mansell Pattison. "Behavioral Science Research on the Nature of Glossolalia." Journal of the American Scientific Affiliation 20 (1968): 73-86.

47. John P. Kildahl. The Psychology of Speaking in Tongues. London: Hodder and Stoughton, UK, 1972, 110.

48. Daniel A. Tappeiner. "The Function of Tongue-Speaking for the Individual: A Psycho-Theological Model." Journal of American Scientific Affiliation 26 (1974): 29-32.

49. Daniel S. Smith, and J. Roland Fleck. "Personality Correlates of Conventional and Unconventional Glossolalia.” Journal of Social Psychology 114 (1981): 209-17. doi: 10.1080/ 00224545.1981 .9922750 .

50. Nicholas P. Spandos, Wendy, P. Cross, Mark Lepage, and Marjorie Coristine. "Glossolalia as Learned Behavior: An Experimental Demonstration." Journal of Abnormal Psychology 95 (1968): 21-23.

51. Leslie J. Francis, Paul R. Pearson, and William K. Kay. "Are Religious Children Bigger Liars?" Psychological Reports 52 (1983): 551-54. doi: 10.2466/pr0.1983.52.2.551.

52. William J. Samarin. “Glossolalia as Regressive Speech.” Language and Speech 16 (1973): 77-79. dio: $10.1177 / 002383097301600108$.

53. Leslie J. Francis, Laurence B. Brown, and Ronald Philipchalk. "The Development of an Abbreviated Form of the Revised Eysenck Personality Questionnaire (EPQR-A): Its Use Among Students in England, Canada, the USA and Australia." Personality Individual Differences 13 (1992): 443-49. dio: http://dx.doi.org/10.1016/0191-8869(92)90073-X.

54. Robert F. DeVellis. Scale Development: Theory and Applications. Sage: London, UK, 2003, 216.

(C) 2013 by the authors; licensee MDPI, Basel, Switzerland. This article is an open access article distributed under the terms and conditions of the Creative Commons Attribution license (http://creativecommons.org/licenses/by/3.0/). 